\title{
Synthesis and Spectral Characterization Studies of New Trimethoprim-Diphenylphosphate Metal Complexes
}

\author{
Abdel-Nasser M. A. Alaghaz ${ }^{1}$, Rabie S. Farag², Mohammed A. Elnawawy ${ }^{3}$, Ahmed D. A. Ekawy ${ }^{4}$ \\ ${ }^{1,2,3,4}$ Department of Chemistry, Faculty of Science, Al-Azhar University, Nasr City, Cairo, Egypt. (E mail address:
}

\begin{abstract}
Eight mononuclear Mn(II), Fe(III), Co(II), Ni(II), Cu(II), Zn(II), Pb(II) and La(III) complexes of DPTMEBPP ligand were synthesized and determined by different physical techniques. The molar ratio for all synthesized complexes is M: DPTMEBPP = 1:1 which was established from the results of chemical analysis. All the eight metal complexes are reported using elemental analysis, molar conductance, magnetic susceptibility, IR, UV-Vis, thermal analysis and ${ }^{1} \mathrm{H}-\mathrm{NMR},{ }^{13} \mathrm{C} N M R$, mass, XRD spectral studies. The molar conductance measurements of all the complexes in DMSO solution correspond to nonelectrolytic nature. The crystal field splitting, Racah repulsion and nepheloauxetic parameters and determined from the electronic spectra of the complexes. The presence of coordinated water molecules were confirmed by thermal studies. All complexes were of the high-spin type and found to have sixcoordinate octahedral geometry except the $\mathrm{Cu}(\mathrm{II}), \mathrm{Zn}(\mathrm{II})$ and $\mathrm{Pb}(\mathrm{II})$ complexes which were four coordinate, square planar geometry for $\mathrm{Cu}(I I)$ complex while tetrahedral geometry for $\mathrm{Zn}(\mathrm{II})$ and $\mathrm{Pb}(\mathrm{II})$ complexes.
\end{abstract}

Keywords: Trimethoprim; diphenylphosphate; Transition metal complexes; Spectra

\section{Introduction}

Trimethoprim, chemically 5-(3,4,5-trimethoxybenzyl) pyrimidine-2,4-diamine, belongs to the class of chemotherapeutic agents known as dihydrofolate reductase inhibitors. It is used in prophylaxis treatment and urinary tract infections [1]. The application of inorganic chemistry to medicine ("Elemental Medicine") is a rapidly developing field, and novel therapeutic and diagnostic metal complexes have an impact on medical practice. Advances in biocoordination chemistry are crucial for improving the design of compounds to reduce toxic side-effects and understand their mechanisms of action. Most of the major classes of pharmaceutical agents contain examples of metal compounds which are in current clinical use [2], and new areas of application are rapidly emerging. Some of these are discussed briefly below with special emphasis on the targeting of metal complexes and their bio-transformation. Targeting is important because the toxicity is often associated with metal compounds. If they can be delivered only to the tissues, cells and receptors where they are required, the toxicity may be reduced. The ease with which many metal complexes undergo ligand substitution and redox reactions is likely to mean that the active species are bio-transformation products of the administered complex. Identification of these active species will lead to the more effective use of metal compounds as drugs. Compounds containing pyrimidine rings play a significant role in many biological systems [3]. The pyrimidine ring system, present in nucleic acids, several vitamins, coenzymes and antibiotics, provides potential binding sites for metal ions, and any information on their coordinating properties is important as a means of understanding the role of the metal ions in biological systems. Many compounds of therapeutic importance contain the pyrimidine ring system. So, substituted 2,4-diaminopyrimidines are widely employed as metabolic inhibitors of pathways leading to the synthesis of proteins and nucleic acids. Among these kinds of ligands, TMP is a well known biological agent, also employed as a potent metabolic inhibitor of bacterial dihydrofolic acid reductase. Trimethoprim has potential binding sites for metal ions. Several authors have studied the interaction of this ligand with biological metal ions and the coordination of TMP via a $\mathrm{NH}_{2}$ nitrogen atom has been inferred on the basis of IR and visible measurements [4,5]. However, other authors have shown by X-ray diffraction methods that the coordination site of the TMP molecule is the N1 of the pyrimidine ring [6-10]. On the other hand, more recently, other research groups [11-16] have prepared and characterized complexes of TMP with metal(II)/(III) and the spectral and analytical data show that the ligand acts as a monodentate or bidentate.

The present work is focused on preparation and structural elucidation of a new ligand, diphenyl (2-amino-5-(3,4,5trimethoxybenzyl)pyrimidin-4-yl-phosphoramidate (DPTMEBPP) as well as its complexes with $\mathrm{Mn}(\mathrm{II}), \mathrm{Fe}(\mathrm{III})$, $\mathrm{Co}(\mathrm{II}), \mathrm{Ni}(\mathrm{II}), \mathrm{Cu}(\mathrm{II}), \mathrm{Zn}(\mathrm{II}), \mathrm{Pb}(\mathrm{II})$ and $\mathrm{La}(\mathrm{III})$ metal ions.

\section{Experimental}

\subsection{Synthesis of diphenyl (2-amino-5-(3,4,5- trimethoxybenzyl)pyrimidin-4-yl-phosphoramidate (DPTMEBPP)}

Asolution of diphenylcholrophosphate $(6.2 \mathrm{ml}, 0.03 \mathrm{~mole})$ indry benzene $(100 \mathrm{ml})$ was added dropwise toawell stirred solution of trimethoprim ([17] $8.7 \mathrm{gm}, 0.03$ mole ) and triethyl amin ( $4.16 \mathrm{ml}, 0.03$ mole ) in drybenzene after the complete addition of diphenylchlorophosphate on cooling. The mixture was heated under reflux for 5 hours. The formed solid (triethylaminehydrochlorid) was filtered off and filterate was evaporated under vacuo obtain solid was recrystallized from ethanol give ( $13.5 \mathrm{gm}, 85 \%$ yield) white bowder m.p (158-160) under reflux for three hours. The purity of the product was checked was by TLC. Yield: $92 \%$ and the melting point is $132^{\circ} \mathrm{C}$ (Table 1). 


\section{International Journal of Science and Research (IJSR) \\ ISSN (Online): 2319-7064}

Index Copernicus Value (2013): 6.14 | Impact Factor (2014): 5.611

\subsection{Synthesis of metal (II/III) complexes}

Solution of manganese acetate $\mathrm{Mn}\left(\mathrm{CH}_{3} \mathrm{COO}\right)_{2} \cdot 4 \mathrm{H}_{2} \mathrm{O}$, Iron nitrate $\mathrm{Fe}\left(\mathrm{NO}_{3}\right)_{3} \cdot 9 \mathrm{H}_{2} \mathrm{O}$, cobalt acetate $\mathrm{Co}\left(\mathrm{CH}_{3} \mathrm{COO}\right)_{2} \cdot 4 \mathrm{H}_{2} \mathrm{O}$, nickle $\mathrm{Ni}\left(\mathrm{CH}_{3} \mathrm{COO}\right)_{2} \cdot 4 \mathrm{H}_{2} \mathrm{O}$, copper acetate $\mathrm{Cu}\left(\mathrm{CH}_{3} \mathrm{COO}\right)_{2} \cdot \mathrm{H}_{2} \mathrm{O}$, zinc acetate $\mathrm{Zn}\left(\mathrm{CH}_{3} \mathrm{COO}\right)_{2} .2 \mathrm{H}_{2} \mathrm{O}$, Lead acetate $\mathrm{pb}\left(\mathrm{CH}_{3} \mathrm{COO}\right)_{2} .2 \mathrm{H}_{2} \mathrm{O}$ and Lanthanium cholorid $\mathrm{LaCl}_{3} .7 \mathrm{H}_{2} \mathrm{O}(0.002$ mole $)$ in dry ethanol $(50 \mathrm{ml})$ were added dropwies to a solution of [(I) 0.002 mole] at room temperature with continuous stirring, the reaction mixture was heated data are listed in Table 1.

Table 1: Elemental analysis and Physico-analytical data for DPTMEBPP ligand and its metal complexes

\begin{tabular}{|c|c|c|c|c|c|c|c|c|c|}
\hline \multirow{2}{*}{$\begin{array}{l}\text { Cpd. } \\
\text { M. F. [M.Wt] }\end{array}$} & \multirow{2}{*}{$\begin{array}{l}\text { m.p. } \\
\left({ }^{\circ} \mathrm{C}\right)\end{array}$} & \multirow{2}{*}{$\begin{array}{l}\text { Color [Yield } \\
(\%)]\end{array}$} & \multicolumn{6}{|c|}{ Elemental analyses $\%$ calculated (found) } & \multirow[t]{2}{*}{${ }^{\mathrm{a}} \Lambda_{\mathrm{m}}$} \\
\hline & & & $\mathrm{M}$ & $\mathrm{C}$ & $\mathrm{H}$ & $\mathrm{N}$ & $\mathrm{P}$ & $\mathrm{Cl}$ & \\
\hline [DPTMEBPP] $\mathrm{C}_{26} \mathrm{H}_{27} \mathrm{~N}_{4} \mathrm{O}_{6} \mathrm{P}$ [522.49] & 132 & Brown[88] & - & $\begin{array}{c}59.77 \\
(59.65)\end{array}$ & $\begin{array}{c}5.21 \\
(5.14)\end{array}$ & $\begin{array}{c}10.72 \\
(10.63)\end{array}$ & $\begin{array}{c}5.93 \\
(5.87)\end{array}$ & - & - \\
\hline $\begin{array}{c}\left.\text { (1)[Mn(DPTMEBPP })\left(\mathrm{H}_{2} \mathrm{O}\right)_{2}(\mathrm{OAc})_{2}\right] 2 \mathrm{H}_{2} \mathrm{O} \\
\mathrm{C}_{30} \mathrm{H}_{41} \mathrm{MnN}_{4} \mathrm{O}_{14} \mathrm{P}[767.58]\end{array}$ & 189 & $\begin{array}{c}\text { Apple-green } \\
{[89]}\end{array}$ & $\begin{aligned} 7.16 \\
(7.16( \\
\end{aligned}$ & $\begin{array}{c}46.94 \\
(46.94) \\
\end{array}$ & \begin{tabular}{|c|c|}
5.38 \\
$(5.38)$ \\
\end{tabular} & $\begin{array}{c}7.30 \\
(7.30) \\
\end{array}$ & $\begin{array}{c}4.04 \\
(4.04) \\
\end{array}$ & - & 20.20 \\
\hline $\begin{array}{l}\left.\text { (2)[Fe(DPTMEBPP)(H }\left(\mathrm{H}_{2} \mathrm{O}\right)\left(\mathrm{NO}_{3}\right)_{3}\right] 6.75 \mathrm{H}_{2} \mathrm{O} \\
\mathrm{C}_{26} \mathrm{H}_{42.5} \mathrm{FeN}_{7} \mathrm{O}_{22.75} \mathrm{P}[903.97]\end{array}$ & 192 & Orange-red [90] & $\begin{array}{r}6.18 \\
(6.18( \\
\end{array}$ & $\begin{array}{c}34.55 \\
(34.55) \\
\end{array}$ & $\begin{array}{c}4.74 \\
(4.74) \\
\end{array}$ & $\begin{array}{c}10.85 \\
(10.85)\end{array}$ & $\begin{array}{c}3.43 \\
(3.43) \\
\end{array}$ & - & 7.33 \\
\hline $\begin{array}{l}\text { (3) }\left[\mathrm{Co}(\mathrm{DPTMEBPP})\left(\mathrm{H}_{2} \mathrm{O}\right)_{2}(\mathrm{OAc})_{2}\right] 2 \mathrm{H}_{2} \mathrm{O} \\
\mathrm{C}_{30} \mathrm{H}_{41} \mathrm{CoN}_{4} \mathrm{O}_{14} \mathrm{P}[771.57]\end{array}$ & 188 & $\begin{array}{c}\text { Cannery-yellow } \\
{[88]}\end{array}$ & $\begin{array}{c}7.64 \\
(7.64( \\
\end{array}$ & $\begin{array}{l}46.70 \\
(46.70)\end{array}$ & $\begin{array}{c}5.36 \\
(5.36)\end{array}$ & $\begin{array}{c}7.26 \\
(7.26)\end{array}$ & $\begin{array}{c}4.01 \\
(4.01) \\
\end{array}$ & - & 18.05 \\
\hline $\begin{array}{l}(4)\left[\mathrm{Ni}(\text { DPTMEBPP })\left(\mathrm{H}_{2} \mathrm{O}\right)_{2}(\mathrm{OAc})_{2}\right] 2 \mathrm{H}_{2} \mathrm{O} \\
\mathrm{C}_{30} \mathrm{H}_{41} \mathrm{~N}_{4} \mathrm{NiO}_{14} \mathrm{P}[771.33]\end{array}$ & 186 & Green [91] & $\begin{array}{r}7.61 \\
(7.61( \\
\end{array}$ & $\begin{array}{c}46.71 \\
(46.63) \\
\end{array}$ & $\begin{array}{c}5.36 \\
(5.36) \\
\end{array}$ & $\begin{array}{c}7.26 \\
(7.32) \\
\end{array}$ & $\begin{array}{r}4.02 \\
(4.02( \\
\end{array}$ & - & 16.53 \\
\hline $\begin{array}{l}\text { (5) }\left[\mathrm{Cu}(\mathrm{DPTMEBPP})(\mathrm{OAc})_{2}\right] \mathrm{H}_{2} \mathrm{O} \\
\mathrm{C}_{30} \mathrm{H}_{35} \mathrm{CuN}_{4} \mathrm{O}_{11} \mathrm{P}[722.14]\end{array}$ & 193 & Dark green [90] & $\begin{aligned} 8.80 \\
(8.80( \\
\end{aligned}$ & $\begin{array}{c}49.90 \\
(49.90) \\
\end{array}$ & \begin{tabular}{|c|}
4.89 \\
$(4.89)$ \\
\end{tabular} & $\begin{array}{c}7.76 \\
(7.34) \\
\end{array}$ & $\begin{array}{c}4.29 \\
(4.29) \\
\end{array}$ & - & 15.55 \\
\hline $\begin{array}{l}\text { (6) }\left[\mathrm{Zn}(\mathrm{DPTMEBPP})(\mathrm{OAc})_{2}\right] 2 \mathrm{H}_{2} \mathrm{O} \\
\mathrm{C}_{30} \mathrm{H}_{37} \mathrm{~N}_{4} \mathrm{O}_{12} \mathrm{PZn}[741.99]\end{array}$ & 197 & Dark brown [84] & $\begin{array}{c}8.81 \\
(8.68( \\
\end{array}$ & $\begin{array}{c}48.56 \\
(48.35)\end{array}$ & \begin{tabular}{|c|}
5.03 \\
$(4.97)$ \\
\end{tabular} & $\begin{array}{c}7.55 \\
(7.33) \\
\end{array}$ & $\begin{array}{c}4.17 \\
(4.12)\end{array}$ & - & 10.12 \\
\hline $\begin{array}{l}\text { (7) }\left[\mathrm{Pb}(\mathrm{DPTMEBPP})(\mathrm{OAc})_{2}\right] 3 \mathrm{H}_{2} \mathrm{O} \\
\mathrm{C}_{30} \mathrm{H}_{39} \mathrm{~N}_{4} \mathrm{O}_{13} \mathrm{PPb}[901.82]\end{array}$ & 187 & Orange [88] & $\begin{array}{r}22.98 \\
(22.83( \\
\end{array}$ & $\begin{array}{l}39.95 \\
(39.95) \\
\end{array}$ & $\begin{array}{c}3.30 \\
(3.29) \\
\end{array}$ & $\begin{array}{c}7.06 \\
(7.00) \\
\end{array}$ & $\begin{array}{c}3.43 \\
(3.34) \\
\end{array}$ & - & 10.25 \\
\hline $\begin{array}{l}\left.\text { (8)[La(DPTMEBPP) }\left(\mathrm{H}_{2} \mathrm{O}\right) \mathrm{Cl}_{3}\right] 6 \mathrm{H}_{2} \mathrm{O} \\
\mathrm{C}_{26} \mathrm{H}_{41} \mathrm{Cl}_{3} \mathrm{LaN}_{4} \mathrm{O}_{13} \mathrm{P}[893.86]\end{array}$ & 187 & Orange [88] & $\begin{aligned} 14.16 \\
(14.14(\end{aligned}$ & $\begin{array}{c}34.94 \\
(34.38)\end{array}$ & $\begin{array}{c}4.62 \\
(4.52)\end{array}$ & $\begin{array}{c}6.27 \\
(6.15) \\
\end{array}$ & $\begin{array}{c}3.47 \\
(3.40)\end{array}$ & $\begin{array}{r}11.90 \\
(11.73( \\
\end{array}$ & 10.25 \\
\hline
\end{tabular}

${ }^{\mathrm{a}} \Lambda_{\mathrm{m}}$ : molar conductance $\left(\Omega^{-1} \mathrm{mo}^{-1} \mathrm{~cm}^{2}\right)$

\subsection{Physical Measurements}

Elemental analyses (CHNS) were carried out on a Perkin Elmer CHNS 2400. The percentage of the metal ions were determined gravimetrically by transforming the solid products into metal oxide or sulfate and also determined by using atomic absorption method. The molar conductance of solid chelates in DMSO was measured using Sybron-Barnstead conductometer (Meter-PM.6, E = 3406). Their IR spectra were recorded on Perkin-Elmer FT-IR spectrophotometer in nujol mull and polyethylene pellets. The UV-visible absorption spectra were recorded using Jasco V-350 recording spectrophotometer at room temperature. Magnetic susceptibility of the metal complexes were measured by the Gouy method at room temperature using a Johnson Matthey, Alpha products, model MKI magnetic susceptibility balance and the effective magnetic moments were calculated using the relation $\mu_{\text {eff }}=2.828$ $\left(\chi_{\mathrm{m}} \cdot \mathrm{T}\right)^{1 / 2} \mathrm{~B} \cdot \mathrm{M}$, where $\chi_{\mathrm{m}}$ is the molar susceptibility corrected using Pascal 's constants for diamagnetism of all atoms in the compounds. The mass spectra were recorded by the EI technique at $70 \mathrm{eV}$ using MS-5988 GC-MS HewlettPackard instrument in the Microanalytical Center, Cairo University. The ${ }^{1} \mathrm{H}(300 \mathrm{MHz})$ and ${ }^{13} \mathrm{C}$ NMR $(75 \mathrm{MHz})$ spectra were recorded using $300 \mathrm{MHz}$ Varian-Oxford Mercury. The deuterated solvent used was dimethylsulphoxide (DMSO) and the spectra extended from 0 to $15 \mathrm{ppm}$. The TGA were recorded on a Shimadzu TGA-50 H. TGA was carried out in a dynamic nitrogen atmosphere $\left(20 \mathrm{~mL} \mathrm{~min}^{-1}\right)$ with a heating rate of $10{ }^{\circ} \mathrm{Cmin}^{-1}$. EPR spectrum of $\mathrm{Cu}$ (II) the complex was recorded as polycrystalline samples, at room temperature, on an E4-EPR spectrometer using the DPPH as the $g$-marker. The X-ray diffraction patterns for the obtained $\mathrm{CT}$ complexes were collected on a PAN anlytical X'Pert PRO X-ray powder diffractometer at the Central Lab at college for girls, Ain Shams University, Egypt University, Egypt.

\section{Results and Discussion}

In this study, metal(II/III) complexes of DPTMEBPP have been prepared and characterized by the analytical and spectroscopic methods. The separated complexes are stable in air, insoluble in water and common organic solvents, but completely soluble in DMSO. The elemental analysis, color, and melting point together with the formula weight obtained from the mass spectra for the complexes are given in Table 1 and agree very well with molecular formula proposed. The analytical data show the composition of the metal complexes to be $\left[\mathrm{Mn}(\mathrm{DPTMEBPP})(\mathrm{OAc})_{2}\left(\mathrm{H}_{2} \mathrm{O}\right)_{2}\right] \cdot 2 \mathrm{H}_{2} \mathrm{O}$, [Fe(DPTMEBPP) $\left.\left(\mathrm{NO}_{3}\right)_{3}\left(\mathrm{H}_{2} \mathrm{O}\right)_{2}\right] \cdot 6.75 \mathrm{H}_{2} \mathrm{O}, \quad$ [Co(DPTMEBPP $\left.(\mathrm{OAc})_{2}\left(\mathrm{H}_{2} \mathrm{O}\right)_{2}\right] \cdot 2 \mathrm{H}_{2} \mathrm{O}, \quad[\mathrm{Ni}(\mathrm{DPTMEBPP})$ $\left.(\mathrm{OAc})_{2}\left(\mathrm{H}_{2} \mathrm{O}\right)_{2}\right] \cdot 2 \mathrm{H}_{2} \mathrm{O}, \quad\left[\mathrm{Cu}(\mathrm{DPTMEBPP})-(\mathrm{OAc})_{2}\right] \cdot \mathrm{H}_{2} \mathrm{O}$, [Zn(DPTMEBPP $\left.)(\mathrm{OAc})_{2}\right] .2 \mathrm{H}_{2} \mathrm{O}, \quad[\mathrm{Pb}(\mathrm{DPTMEBPP})-$ $\left.(\mathrm{OAc})_{2}\right] \cdot 3 \mathrm{H}_{2} \mathrm{O}$ and $\left[\mathrm{La}(\mathrm{DPTMEBPP})(\mathrm{Cl})_{3}\left(\mathrm{H}_{2} \mathrm{O}\right)_{2}\right] \cdot 6 \mathrm{H}_{2} \mathrm{O}$. The ratios of the metal present in all complexes have been determined by atomic absorption spectroscopy. The complexes have been decomposed in $\mathrm{HNO}_{3} / \mathrm{HClO}_{4}(2 / 1)$ and then dissolved in $1.5 \mathrm{~N} \mathrm{HClO}_{4}$. The amounts of metals have been determined (Table 1). The molar conductivity measurements have been done all compounds in DMF $\left(\sim 1.10^{-3} \mathrm{M}\right.$ solutions). The conductivity data of the complexes are very low and they can be regarded as non-electrolytes[16]. Chloride ion in the [La(DPTMEBPP $\left.)(\mathrm{Cl})_{3}\left(\mathrm{H}_{2} \mathrm{O}\right)_{2}\right] \cdot 6 \mathrm{H}_{2} \mathrm{O}$ complex has been determined by titration with $\mathrm{AgNO}_{3}$. 


\section{International Journal of Science and Research (IJSR) \\ ISSN (Online): 2319-7064 \\ Index Copernicus Value (2013): 6.14 | Impact Factor (2014): 5.611}

Various attempts, such as crystallization using mixtures of solvents and low temperatures, were unsuccessful for the growth of a single crystal suitable for X-ray crystallography. However, the analytical, spectroscopic and magnetic data enabled the possible structure of the synthesized complexes to be predicted. The DPTMEBPP ligand and its metal complexes which we studied have not been previously reported in the literature.

\subsection{The DPTMEBPP ligand}

The analytically pure ligand DPTMEBPP (Figure 1) was readily synthesized with very good yield (90\%) by phosphoramidate reaction of TMP (5-(3,4,5-trimethoxybenzyl)-pyrimidine-2,4-diamine) with equimolar of diphenylchlorophosphate in acetonitrile. The ligand DPTMEBPP may show keto-enol tautomerism because it contains the phosphenous amide $(-\mathrm{NH}-\mathrm{P}=\mathrm{O})$ bonds [18-21]. The IR spectrum does not show a $v(\mathrm{OH})$ band at or $3400 \mathrm{~cm}^{-1}$ but shows the band at $3273 \mathrm{~cm}^{-1}$ corresponding to $v(\mathrm{NH})$ [18-21], indicating that in solid state, the ligand exists in the keto form for the ligand DPTMEBPP. However, the ${ }^{1} \mathrm{H}$ NMR spectrum of ligand shows a singlet at $9.75 \mathrm{ppm}$ corresponding to $\mathrm{OH}$ groups which suggest the existence of ligand in enolic form in solution. The ${ }^{31} \mathrm{P}$ NMR of the ligand records a signal at $\delta=14.45 \mathrm{ppm}$, which supports the phosphenous amide group $[18-21]$. In the ${ }^{13} \mathrm{C}$ NMR spectrum three peaks at $163.8 \mathrm{ppm}$, $158.8 \mathrm{ppm}, 58.3 \mathrm{ppm}$ and $32.5 \mathrm{ppm}$ were observed, being assigned to $\mathrm{C}=\mathrm{N}, \mathrm{C}-\mathrm{OP}, \mathrm{CH}_{2}$ and $\mathrm{CH}_{3}$, respectively. The electronic spectrum of DPTMEBPP in ethanol showed absorption bands at $240-390 \mathrm{~nm}$ regions which is due to intraligand $\pi \rightarrow \pi^{*}$ and $\mathrm{n} \rightarrow \pi^{*}$ transitions involving molecular orbital of the pyrimidine ring, a broad shoulder at approximately $432 \mathrm{~nm}$ were observed. The latter band is attributed to an $\mathrm{n}$ (oxygen) $\rightarrow \pi^{*}$ transition of the dipolar zwitter ionic structure or keto-amine tautomer of DPTMEBPP [18-21]. The electron impact mass spectrum (Figure 2) of the free ligand, confirms the proposed formula by showing a peak at $522 \mathrm{u}$ corresponding to the ligand moiety $\left[\left(\mathrm{C}_{26} \mathrm{H}_{27} \mathrm{~N}_{4} \mathrm{O}_{6} \mathrm{P}\right)\right.$ atomic mass $\left.522 \mathrm{u}\right]$. The series of peaks in the range, i.e. $60,71,86,10,125,149,157,179,185$, 199, 213, 236, 243, 256, 279, 292, 296, 309, 326, 348, 358, 368, 386, 395, 417, 432, 443, 452, 470, 491 and $509 \mathrm{u}$, etc., may be assigned to various fragments and their intensity gives an idea of stability of fragments. The mass spectrum of the ligand (DPTMEBPP) shows the fragmentation pattern in Scheme 1.

Figure 1: Proposed structure of DPTMEBPP ligand 


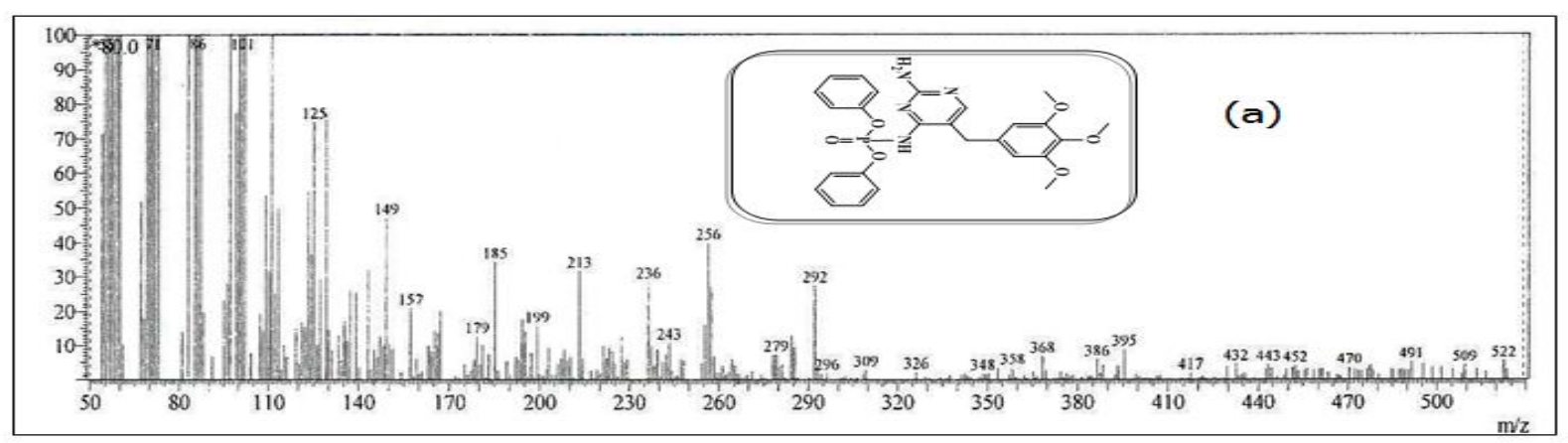

Figure 2: Mass spectrum of DPTMEBPP ligand.

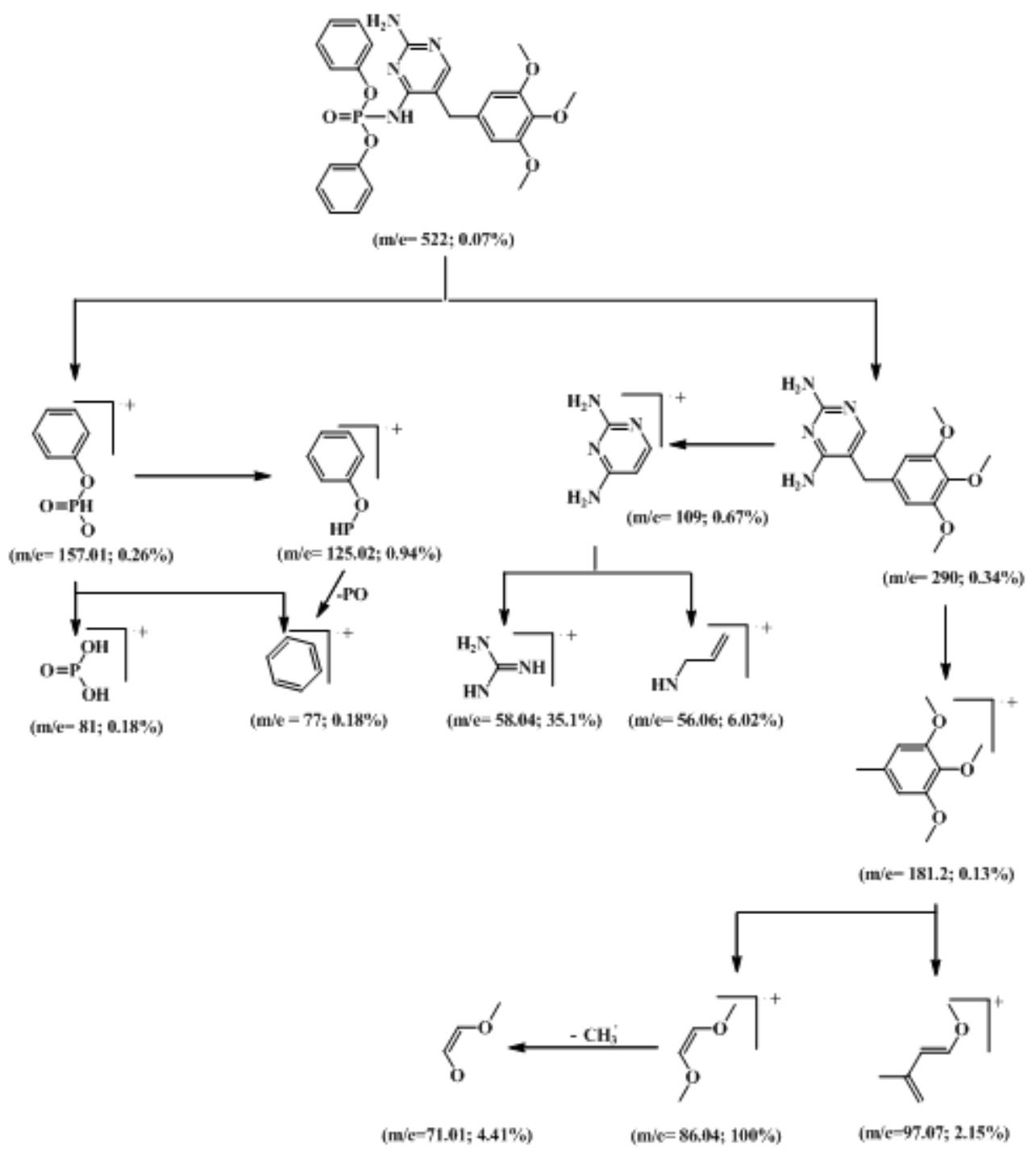

Scheme 1: Fragmentation pattern of DPTMEBPP ligand

\subsection{Characterization of metal(II/III) complexes}

\subsubsection{Infrared spectra and mode of bonding}

In the absence of a powerful technique such as X-ray crystallography, IR spectra have proven to be the most suitable technique to give enough information es to elucidate the nature of bonding of the ligand to the metal ion. The IR spectra of the free ligand and metal complexes were carried out in the range $4000-400 \mathrm{~cm}^{-1}$. The IR spectra of the ligand and its metal complexes were found to be very similar to each other. DPTMEBPP possesses seven potential donor sites; two pyrimidinyl $\mathrm{N}$ atoms, one $\mathrm{NH}_{2}$ and one $\mathrm{NH}$ groups on the pyrimidine rings, three methoxy groups and phosphate group. So, the $v_{\mathrm{as}}(\mathrm{N}-\mathrm{H})$ and $v_{\mathrm{s}}(\mathrm{N}-\mathrm{H})$ modes of the pyrimidine- $\mathrm{NH}_{2}$ groups in the free DPTMEBPP are assigned to the strong and sharp bands at 3460 and 3312 $\mathrm{cm}^{-1}$, respectively, which are affected by the presence of hydrogen bonds. In all the complexes the bands $v(\mathrm{~N}-\mathrm{H})$, due to asymmetric and symmetric vibrations, are present in the region $3480-3400 \mathrm{~cm}^{-1}$; these bands shifted significantly with respect to those of the ligand. This confirms that the metal ion is coordinated to the trimethoprim through the two $\mathrm{N}$ atoms that belong to $\mathrm{NH}_{2}$ and $\mathrm{NH}$ groups [1]. The $(\mathrm{C}=\mathrm{N})$ stretching vibration band of DPTMEBPP is observed at 


\section{International Journal of Science and Research (IJSR) ISSN (Online): 2319-7064 \\ Index Copernicus Value (2013): 6.14 | Impact Factor (2014): 5.611}

$1650 \mathrm{~cm}^{-1}$. Upon the complex formation, the $(\mathrm{C}=\mathrm{N})$ stretching vibration band is shifted to a lower wave number (between 1645 and $1600 \mathrm{~cm}^{-1}$ ). In the IR spectra of the complexes, a bands are observed at 270-294 and 320-328 $\mathrm{cm}^{-1}$ that is attributed to the $v(\mathrm{M}-\mathrm{N})[22]$ and $v(\mathrm{M}-\mathrm{Cl})$ [22] stretching vibrations, respectively. Another band appeared between 332 and $342 \mathrm{~cm}^{-1}$, which is assigned to the interaction of phenolic oxygen to the metal atom, i.e., the stretching vibrations $v(\mathrm{M}-\mathrm{O})$ [21]. Also, in the IR spectra of the complexes, a bands are observed at 187- 193 and 216$233 \mathrm{~cm}^{-1}$ that is attributed to the $v(\mathrm{O}-\mathrm{M}-\mathrm{O})$ and $v(\mathrm{O}-\mathrm{M}-\mathrm{N})$ $[23,24]$ stretching vibrations, respectively. The bands in the range $744-837 \mathrm{~cm}^{-1}$ and $614-633 \mathrm{~cm}^{-1}$ appeared in the spectra of these complexes which may be assigned to $\operatorname{\rho r}\left(\mathrm{H}_{2} \mathrm{O}\right)$ and $\rho w\left(\mathrm{H}_{2} \mathrm{O}\right)$ [22]. IR spectra of nitrate complex displays three $(\mathrm{N}-\mathrm{O})$ stretching bands, at $\sim 1414 \mathrm{~cm}^{-1}\left(v_{5}\right)$, $1305 \mathrm{~cm}^{-1}\left(v_{1}\right)$ and $1004 \mathrm{~cm}^{-1}\left(v_{2}\right)$. The separation of two highest frequency bands $\left(v_{5}-v_{1}\right), \Delta$ is $109 \mathrm{~cm}^{-1}$. Suggesting that both the nitrate groups are coordinated to the central metal ion $[24,25]$ in unidentate manner.

\subsubsection{NMR spectra}

The ${ }^{1} \mathrm{H}$ NMR spectra of the DPTMEBPP and its complexes have been recorded using DMSO. In the spectrum of the DPTMEBPP, the $-\mathrm{CH}_{2}$ protons are seen at $3.42 \mathrm{ppm}$ as singlet. The singlets in the 3.77 and $3.54 \mathrm{ppm}$ can be attributed to the methoxy protons. The slightly broad bands at the 5.71 and $6.10 \mathrm{ppm}$ can be attributed to the $\mathrm{NH}_{2}$ and $\mathrm{NH}$ protons. The aromatic protons are shown at 6.58 and $7.55 \mathrm{ppm}$ as singlets. In the spectra of the complexes, the $\mathrm{NH}_{2}$ and $\mathrm{NH}$ protons have been shifted to the lower regions and this situation confirms that the nitrogen atom of the amine and imine groups coordinates to the metal ions. The signal observed at $3.33 \mathrm{ppm}$ with an integration corresponding to four, four and fourteen protons in case of $\mathrm{Zn}(\mathrm{II}), \mathrm{Pb}(\mathrm{II})$ and $\mathrm{La}(\mathrm{III})$ complexes are assigned to two, three and eight water molecules, respectively.

\subsubsection{Electronic spectra and magnetic behavior}

The significant electronic spectra of the ligand and complexes are recorded in DMSO. The important bands of the ligand are observed in the region of 430-332 nm.

The magnetic moments of the complexes (as B.M.) were measured at room temperature. The effective magnetic moment values for Mn(DPTMEBPP), Fe(DPTMEBPP), Co(DPTMEBPP), Ni(DPTMEBPP) and Cu(DPTMEBPP) complexes were 5.98, 5.84, 5.08, 3.24 and 1.89 B.M., respectively. Low magnetic moment values support octahedral configurations for the $\mathrm{Mn}(\mathrm{II}), \mathrm{Fe}(\mathrm{III}), \mathrm{Co}(\mathrm{II})$, $\mathrm{Ni}(\mathrm{II})$ and $\mathrm{Cu}(\mathrm{II})$ complexes [23].
Electronic spectrum of the manganese(II) complex displays weak absorption bands at 18,178, 24,734, 29,633 and 31,835 $\mathrm{cm}^{-1}$ corresponding to an octahedral geometry. These bands may be assigned to ${ }^{6} \mathrm{~A}^{1} \mathrm{~g} \rightarrow{ }^{4} \mathrm{~T}_{1} \mathrm{~g}(4 \mathrm{G}),{ }^{6} \mathrm{~A}_{1} \mathrm{~g} \rightarrow{ }^{4} \mathrm{E}_{2} \mathrm{~g},{ }^{4} \mathrm{~A}_{1} \mathrm{~g}$ (4G), ${ }^{6} \mathrm{~A}_{1} \mathrm{~g} \rightarrow{ }^{4} \mathrm{E}_{2} \mathrm{~g}$ (4D), and ${ }^{6} \mathrm{~A}_{1} \mathrm{~g} \rightarrow{ }^{4} \mathrm{~T}_{1} \mathrm{~g}$ (4P) transitions, respectively [23]. Electronic spectrum of of the iron(III) complex exhibits three spectral bands at 16,542 $\left(v_{1}\right), 20,746$ $\left(v_{2}\right)$ and $25,947 \mathrm{~cm}^{-1}\left(v_{3}\right)$ corresponding to an octahedral geometry [23]. Electronic spectrum of the cobalt(II) complex exhibits a broad band at $8827 \mathrm{~cm}^{-1}$ and two shoulders at 14,536 and $20,857 \mathrm{~cm}^{-1}$. These bands may be assigned to ${ }^{4} \mathrm{~T}_{1} \mathrm{~g} \rightarrow{ }^{4} \mathrm{~T}_{2} \mathrm{~g} \quad\left(v_{1}\right),{ }^{4} \mathrm{~T}_{1} \mathrm{~g} \rightarrow{ }^{4} \mathrm{~A}_{2} \mathrm{~g} \quad\left(v_{2}\right), \quad$ and ${ }^{4} \mathrm{~T}_{1} \mathrm{~g} \rightarrow{ }^{4} \mathrm{~T}_{2} \mathrm{~g}(\mathrm{P})\left(v_{3}\right)$ transitions, respectively [24,25]. The low value of $v_{2} / v_{1}=1.66$ may be due to distortion of the octahedral structure. This is consistent with vary broad nature of the $v_{1}$ band which may be assigned to the envelop of the transitions from ${ }^{4} \mathrm{Eg}\left({ }^{4} \mathrm{~T}_{1} \mathrm{~g}\right)$ to the components ${ }^{4} \mathrm{~B}_{2} \mathrm{~g}$ and ${ }^{4} \mathrm{Eg}$ of ${ }^{4} \mathrm{~T}_{2} \mathrm{~g}$ characteristic of tetragonally distorted octahedral environment. Electronic spectrum of the nickel(II) complex displays two well-defined bands at 10,664 and $16,623 \mathrm{~cm}^{-1}$. These may be assigned to ${ }^{3} \mathrm{~A}_{2} \mathrm{~g} \rightarrow{ }^{3} \mathrm{~T}_{2} \mathrm{~g}(\mathrm{~F})\left(v_{1}\right)$ and ${ }^{3} \mathrm{~A}_{2} \mathrm{~g} \rightarrow{ }^{3} \mathrm{~T}_{2} \mathrm{~g}(\mathrm{~F})\left(v_{2}\right)$ transitions, respectively. In the present study splitting of $v_{1}$ band was not observed which is generally observed in $\mathrm{D}_{4} \mathrm{~h}$ symmetry. So Dt, $\mathrm{Dq}^{\mathrm{E}}, \mathrm{Dq}^{\mathrm{A}}$ cannot be calculated. The third $\mathrm{d}-\mathrm{d}$ transitions band $\left(v_{3}\right)$ which may be obscured by the more intense charge transfer band was calculated to be at $24,614 \mathrm{~cm}^{-1}$. All of these values, are characteristic of an octahedral geometry for the nickel(II) complex[24,25]. Electronic spectrum of the copper(II) complex displays bands at 10,169 $\left(\varepsilon=49 \mathrm{Lmol}^{-1}\right.$ $\left.\mathrm{cm}^{-1}\right), 18,586\left(\varepsilon=64 \mathrm{Lmol}^{-1} \mathrm{~cm}^{-1}\right)$, and $30,336 \mathrm{~cm}^{-1}(\varepsilon=85 \mathrm{~L}$ $\left.\mathrm{mol}^{-1} \mathrm{~cm}^{-1}\right)$. First two bands may be assigned to the transitions: $\quad{ }^{2} \mathrm{~B}_{1} \mathrm{~g} \rightarrow{ }^{2} \mathrm{~A}_{1} \mathrm{~g} \quad\left(\mathrm{~d} x^{2}-y^{2} \rightarrow \mathrm{d} z^{2}\right) \quad\left(v_{1}\right),{ }^{2} \mathrm{~B}_{1} \mathrm{~g} \rightarrow{ }^{2} \mathrm{~B}_{2} \mathrm{~g}$ $\left(\mathrm{d} x^{2}-y^{2} \rightarrow \mathrm{d} z y\right)\left(v_{2}\right)$, respectively and third band may be due to charge transfer. The complex may have square-planar geometry[25].

\subsection{Ligand field parameters}

Various ligand parameters were calculated for the complexes and are listed in Table 2. The value Dq in Co(II) complexes was calculated from transition energy ratio diagram using the $v_{3} / v_{2}$ ratio The Nephelauxetic parameter $\beta$ was calculated by using the relation $\beta=B$ (complex) $/ B$ (free ion), where $B$ free ion for $\mathrm{Mn}(\mathrm{II}), \mathrm{Fe}(\mathrm{III}), \mathrm{Co}(\mathrm{II})$ is 928,966 , and $912 \mathrm{~cm}^{-1}$. The $\beta$ value lies in the range $0.33-0.97$. These values indicate that the appreciable covalent character of metal ligand $\sigma$ bond [24-27].

Table 2: Ligand field parameters of the complexes

\begin{tabular}{|c|c|c|c|c|c|c|c|c|}
\hline Complex & Dq $\left(\mathrm{cm}^{-1}\right)$ & $\mathrm{B}\left(\mathrm{cm}^{-1}\right)$ & $\beta$ & LFSE $\left(\mathrm{kJmol}^{-1}\right)$ & $F_{2}$ & $F_{4}$ & $C$ & $v_{2} / v_{1}$ \\
\hline$\left[\mathrm{Fe}(\right.$ DPTMEBPP $\left.)\left(\mathrm{NO}_{3}\right)_{3}\left(\mathrm{H}_{2} \mathrm{O}\right)_{2}\right] \cdot 6.75 \mathrm{H}_{2} \mathrm{O}$ & 1689 & 923 & 0.83 & 214 & - & - & - & 1.22 \\
\hline$\left[\mathrm{Mn}(\right.$ DPTMEBPP $\left.)(\mathrm{OAc})_{2}\left(\mathrm{H}_{2} \mathrm{O}\right)_{2}\right] \cdot 2 \mathrm{H}_{2} \mathrm{O}$ & 868 & 964 & 0.88 & - & 1234 & 87 & 3156 & 1.49 \\
\hline$\left[\mathrm{Co}(\mathrm{DPTMEBPP})(\mathrm{OAc})_{2}\left(\mathrm{H}_{2} \mathrm{O}\right)_{2}\right] \cdot 2 \mathrm{H}_{2} \mathrm{O}$ & 1182 & 903 & 0.32 & 96 & - & - & - & 1.64 \\
\hline$\left[\mathrm{Ni}(\mathrm{DPTMEBPP})(\mathrm{OAc})_{2}\left(\mathrm{H}_{2} \mathrm{O}\right)_{2}\right] \cdot 2 \mathrm{H}_{2} \mathrm{O}$ & 798 & - & 0.96 & 113 & - & - & - & 1.82 \\
\hline
\end{tabular}

\subsection{EPR Spectra}

The EPR spectra of the $\mathrm{Cu}(\mathrm{II})$ complex was recorded as polycrystalline sample as well as solution at room temperature at different frequency. In the EPR spectrum of the $\mathrm{Cu}$ (II) complex (Figure 3 ) no band corresponding to $\mathrm{ms}$ $= \pm 2$ transition [22,24, 28- 33] was observed in the spectrum, ruling out any $\mathrm{Cu}-\mathrm{Cu}$ interaction. The $\mathrm{g}$ tensor 


\section{International Journal of Science and Research (IJSR) \\ ISSN (Online): 2319-7064}

Index Copernicus Value (2013): 6.14 | Impact Factor (2014): 5.611

values of $\mathrm{Cu}$ (II) complex can be used to derive the ground state. In octahedral geometry the unpaired electron lies in the $\mathrm{dx}^{2}-\mathrm{y}^{2}$ orbital giving ${ }^{2} \mathrm{~B}_{1} \mathrm{~g}$ as the ground state with $g_{\|}>g_{\perp}$. The $g_{\|}$and $g_{\perp}$ values were computed from the spectrum using DPPH free radicals as,$g^{\text {ee }}$ marker. The $g_{\|}$values are $<$ 2.5 which shoes covalent character of the metal ligand bond.
The trend $g_{\|}>g_{\perp}>2.0023$ observed for these complexes indicates that the unpaired electron is localized in $\mathrm{dx}^{2}-\mathrm{y}^{2}$ orbital of the $\mathrm{Cu}$ (II) ions and the spectral features are characteristics of axial symmetry [34,35].

\subsection{OE+O3 \\ $1.50 \mathrm{E}+03$ \\ $1.00 \mathrm{E}+03$ \\ $5.00 \mathrm{E}+02$ \\ $0.00 \mathrm{E}+00$ \\ $-5.00 \mathrm{E}+02$ \\ $-1.00 \mathrm{E}+03$ \\ $-1.50 \mathrm{E}+03$ \\ $-2.00 \mathrm{E}+03$}

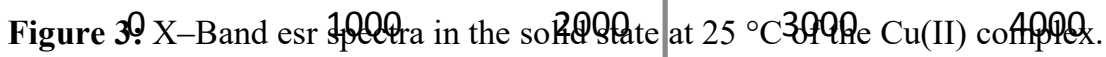

\section{6. $\mathrm{X}$-ray powder diffraction}

Single crystals of the complexes could not be prepared to get the XRD and hence the powder diffraction data were obtained for structural characterization. Structures determination by X-ray powder diffraction (Fig. 4) data have gone through a recent surge since it have becomes important to get to the structural information of materials, which do not yield good quality single crystals. The indexing procedures were performed using $(\mathrm{CCP} 4, \mathrm{UK})$ CRYSFIRE program [36] giving cubic crystal system for [Co(DPTMEBPP) $\left.(\mathrm{OAc})_{2}\left(\mathrm{H}_{2} \mathrm{O}\right)_{2}\right] \cdot 2 \mathrm{H}_{2} \mathrm{O}$ (Fig. 4a) having $\mathrm{M}(6)=14, \mathrm{~F}(6)=8$ and tetragonal crystal system for $\left[\mathrm{Cu}(\mathrm{DPTMEBPP})(\mathrm{OAc})_{2}\right] \cdot \mathrm{H}_{2} \mathrm{O}$ (Fig. 4b) having $\mathrm{M}(9)=12$, $\mathrm{F}(6)=7$ as the best solutions. Their cell parameters are shown in Table 3.

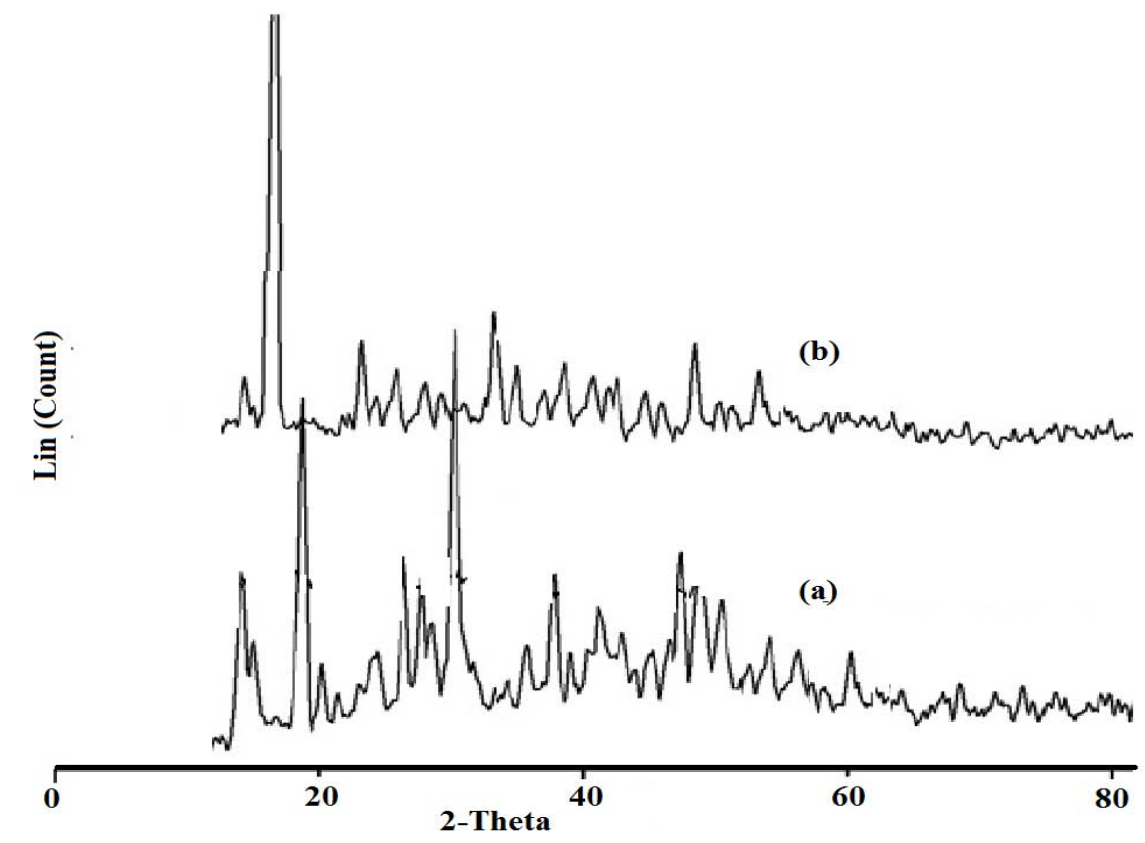

Figure 4: X-ray diffraction patterns of (a) $\mathrm{Co}$ (II) and (b) Co(II) complexes. 


\section{International Journal of Science and Research (IJSR) \\ ISSN (Online): 2319-7064}

Index Copernicus Value (2013): 6.14 | Impact Factor (2014): 5.611

Table 3: Crystallographic data for the Schiff base complexes [Co(DPTMEBPP $\left.)(\mathrm{OAc})_{2}\left(\mathrm{H}_{2} \mathrm{O}\right)_{2}\right] \cdot 2 \mathrm{H}_{2} \mathrm{O}$ and

$\left[\mathrm{Cu}(\mathrm{DPTMEBPP})(\mathrm{OAc})_{2}\right] . \mathrm{H}_{2} \mathrm{O}$.

\begin{tabular}{|l|c|c|}
\hline Data & {$\left[\mathrm{Co}(\right.$ DPTMEBPP $\left.)(\mathrm{OAc})_{2}\left(\mathrm{H}_{2} \mathrm{O}\right)_{2}\right] .2 \mathrm{H}_{2} \mathrm{O}$} & {$\left[\mathrm{Cu}(\mathrm{DPTMEBPP})(\mathrm{OAc})_{2}\right] . \mathrm{H}_{2} \mathrm{O}$} \\
\hline Empirical formula & {$\left[\mathrm{Co}(\mathrm{DPTMEBPP})(\mathrm{OAc})_{2}\left(\mathrm{H}_{2} \mathrm{O}\right)_{2}\right] .2 \mathrm{H}_{2} \mathrm{O}$} & {$\left[\mathrm{Cu}(\mathrm{DPTMEBPP})(\mathrm{OAc})_{2}\right] . \mathrm{H}_{2} \mathrm{O}$} \\
\hline Formula weight $(\mathrm{g} / \mathrm{mol})$ & 771.57 & 722.14 \\
\hline Wavelength $(\AA)$ & 1.54 & 1.54 \\
Crystal system & Tetragonal & Cubic \\
\hline Space group & $\mathrm{P} 4 / \mathrm{m}$ & $\mathrm{P} 4 / \mathrm{m}$ \\
\hline Unit cell dimensions $(\AA)$ & & 15.147 \\
\hline$a(\AA)$ & 7.0112 & 15.147 \\
\hline$b(\AA)$ & 7.0112 & 15.147 \\
\hline$c\left(^{\circ}\right)$ & 15.8718 & 90 \\
\hline$\alpha\left(^{\circ}\right)$ & 90 & 90 \\
\hline$\beta\left(^{\circ}\right)$ & 90 & 90 \\
\hline$\gamma\left({ }^{\circ}\right)$ & 90 & 6018 \\
\hline Volume $\left(\AA^{3}\right)$ & 1103 & 1.21 \\
\hline$($ Calc. $)$ densit $\left(\mathrm{g} / \mathrm{cm}^{-3}\right)$ & 1.83 & $16.45-60 . .14$ \\
\hline $2 \theta$ range & $15.22-55.08$ & $3 \leq h \leq 10,1 \leq k \leq 6,3 \leq l \leq 10$ \\
Limiting indices & $0 \leq \mathrm{h} \leq 3,0 \leq \mathrm{k} \leq 1,1 \leq \mathrm{l} \leq 7$ & 6 \\
$\mathrm{Z}$ & 2 & 0.000019 \\
$R \mathrm{f}$ & 0.0000788 & 298 \\
Temperature $(\mathrm{K})$ & 298 & \\
\hline
\end{tabular}

\subsection{Mass Spectra}

The mass spectrum of the ligand (DPTMEBPP) showed a molecular ion peak at $\mathrm{m} / \mathrm{z}$ 522.49. Fig. 2, which is equivalent to its molecular weight[37,38]. In addition to this, fragmented peak observed at $\mathrm{m} / \mathrm{z} 88$ is due to the cleavage of $-\left(\mathrm{CHOCH}_{3}\right)_{2}$ group. The ESI-MS results of [Mn(DPTMEBPP $\left.)(\mathrm{OAc})_{2}\left(\mathrm{H}_{2} \mathrm{O}\right)_{2}\right] \cdot 2 \mathrm{H}_{2} \mathrm{O}$,

[Fe(DPTMEBPP $\left.)\left(\mathrm{NO}_{3}\right)_{3}\left(\mathrm{H}_{2} \mathrm{O}\right)_{2}\right] \cdot 6.75 \mathrm{H}_{2} \mathrm{O}$,

[Co(DPTMEBPP $\left.)(\mathrm{OAc})_{2}\left(\mathrm{H}_{2} \mathrm{O}\right)_{2}\right] \cdot 2 \mathrm{H}_{2} \mathrm{O}$,

[Ni(DPTMEBPP $\left.)(\mathrm{OAc})_{2}\left(\mathrm{H}_{2} \mathrm{O}\right)_{2}\right] \cdot 2 \mathrm{H}_{2} \mathrm{O}$,

$\left[\mathrm{Cu}(\mathrm{DPTMEBPP})(\mathrm{OAc})_{2}\right] \cdot \mathrm{H}_{2} \mathrm{O}$,

[Zn(DPTMEBPP $\left.)(\mathrm{OAc})_{2}\right] \cdot 2 \mathrm{H}_{2} \mathrm{O}$,

[Pb(DPTMEBPP)$\left.(\mathrm{OAc})_{2}\right] \cdot 3 \mathrm{H}_{2} \mathrm{O}$ and $\left[\mathrm{La}(\mathrm{DPTMEBPP})(\mathrm{Cl})_{3}\left(\mathrm{H}_{2} \mathrm{O}\right)_{2}\right] \cdot 6 \mathrm{H}_{2} \mathrm{O}$ showed $[\mathrm{M}]^{+}$peak at $\mathrm{m} / \mathrm{z} 767.58,903.97,771.57,771.33$, $722.14,741.99,901.82$ and 893.86 equivalent to their molecular weight respectively. All complexes and DPTMEBPP give the fragmentation of the 1,2,3-trimethoxy-5-methylbenzene group, which is observed at $79.2 \mathrm{~m} / \mathrm{z}$.

\subsection{Thermal Analyses}

TG for the complexes were carried out within a temperature range from room temperature up to $800{ }^{\circ} \mathrm{C}$. TGA results are in a good agreement with the suggested formulae resulted from microanalyses data (Table 1).

The TGA data of Fe-complex of DPTMEBPP is thermally decomposed in three stages. The first stage corresponds to the loss of $4.164 \%$ of the weight of complex within the range $28.25-179.62^{\circ} \mathrm{C}$ corresponding to the loss of two water molecule of crystallization. The second stage corresponds to the loss of $11.531 \%$ of the weight of complex within the range $180.55-315^{\circ} \mathrm{C}$ corresponding to the loss of 3.25 water molecule of crystallization, one amino group and one methoxy group $\left[\mathrm{CH}_{3} \mathrm{O}\right]^{+}$. The last stage corresponds to the loss of $40.651 \%$ of the weight of the complex within the range $316-452^{\circ} \mathrm{C}$ that can be attributed to the loss of $\left[\mathrm{C}_{19} \mathrm{H}_{20} \mathrm{~N}_{3} \mathrm{O}_{3} \mathrm{P}\right]^{+}$. The residue $41.813 \%$ of the original weight of the complex, corresponds to the molecular weight of 378 mass unit which can be assigned for $\left[\mathrm{C}_{8} \mathrm{H}_{11} \mathrm{FeN}_{4} \mathrm{O}\right]^{+}$.

The TGA data of $\mathrm{Cu}$-complex of DPTMEBPP is thermally decomposed in two stages. The first stage corresponds to the loss of $61.213 \%$ of the weight of complex within the range $21-341{ }^{\circ} \mathrm{C}$ corresponding to the loss of one water molecule of crystallization and two acetate group associated with the complex and $\left[\mathrm{C}_{14} \mathrm{H}_{17} \mathrm{~N}_{4} \mathrm{O}_{4}\right]^{+}$. The second stage corresponds to the loss of $18 \%$ of the weight of complex within the range $342-999^{\circ} \mathrm{C}$ corresponding to the loss of $\left[\mathrm{C}_{6} \mathrm{H}_{7} \mathrm{OP}\right]^{+}$. The residue $20.765 \%$ of the original weight of the complex, corresponds to the molecular weight of 149.7 mass unit which can be assigned for $\mathrm{CuO}$ and $\left[\mathrm{C}_{6} \mathrm{H}_{5}\right]^{+}$.

The TGA data of Pb-complex of DPTMEBPP is thermally decomposed in five stages. The first stage corresponds to the loss of $5.845 \%$ of the weight of complex within the range $21-179^{\circ} \mathrm{C}$ corresponding to the loss of two water molecule of crystallization and one amino group. The second stage corresponds to the loss of $11.47 \%$ of the weight of complex within the range $180-373^{\circ} \mathrm{C}$ corresponding to the loss of 0.5 water molecule of crystallization and three methoxy group $\left[\mathrm{CH}_{3} \mathrm{O}\right]^{+}$. The third stage corresponds to the loss of $7.399 \%$ of the weight of the complex within the range $374-438^{\circ} \mathrm{C}$ that can be attributed to the loss of one acetate group associated with the complex. The fourth stage corresponds to the loss of $18.616 \%$ of the weight of the complex within the range $439-689^{\circ} \mathrm{C}$ that can be attributed to the loss of $\left[\mathrm{C}_{7} \mathrm{H}_{6} \mathrm{O}_{3} \mathrm{P}\right]^{+}$. The last stage corresponds to the loss of $5.78 \%$ of the weight of complex within the range $690-997^{\circ} \mathrm{C}$ that can be attributed to the loss of $\left[\mathrm{C}_{4} \mathrm{H}_{5}\right]^{+}$. The residue $50.632 \%$ of the original weight of the complex, corresponds to the molecular weight of 456.7 mass unit which can be assigned for $\left[\mathrm{C}_{17} \mathrm{H}_{16} \mathrm{~N}_{2} \mathrm{~Pb}\right]^{+}$.

The TGA data of La-complex of DPTMEBPP is thermally decomposed in two stages. The first stage corresponds to the loss of $49.635 \%$ of the weight of complex within the range $27-534^{\circ} \mathrm{C}$ corresponding to the loss of four water molecule of crystallization and $\left[\mathrm{C}_{14} \mathrm{H}_{17} \mathrm{~N}_{4} \mathrm{O}_{6} \mathrm{P}\right]^{+}$. The second stage 


\section{International Journal of Science and Research (IJSR) \\ ISSN (Online): 2319-7064 \\ Index Copernicus Value (2013): 6.14 | Impact Factor (2014): 5.611}

corresponds to the loss of $22.407 \%$ of the weight of complex within the range $536-998^{\circ} \mathrm{C}$ corresponding to the loss of $\left[\mathrm{C}_{12} \mathrm{H}_{10} \mathrm{O}_{3}\right]^{+}$. The residue $27.88 \%$ of the original weight of the complex, corresponds to the molecular weight of 242 mass unit which can be assigned for $\mathrm{LaCl}_{3}$.

\subsection{Kinetic Studies}

The thermodynamic activation parameters (Table 4-6) of decomposition processes of the metal complexes namely activation energy $\left(E^{*}\right)$, entropy $\left(\Delta S^{*}\right)$ and Gibbs free energy change of the decomposition $\left(\Delta G^{*}\right)$ were evaluated graphically by employing three methods, Horowitz-Metzger [39] (HM), Coats-Redfern [40] (CR), and PiloyanNovikova [41] (PN). From the results obtained, the following remarks can be pointed out:

1) The energy of activation (E) values increases on going from one decomposition stage to another for a given complex, indicating that the rate of decomposition decreases in the same order. Generally stepwise stability constants decreases with an increase in the number of ligand attached to a metal ion. Conversely, during decomposition reaction the rate of removal of remaining ligands will be smaller after the expulsion of the ligand $[42,43]$.

2) The values of $\Delta G$ increases significantly for the subsequently decomposition stages due to increasing the values of $(T \Delta S)$ from one stage to another. This may be attributed to the structural rigidity of the remaining complex after the expulsion of more ligands, as compared with the precedent complex, which require more energy, $\mathrm{T} \Delta \mathrm{S}$, for its rearrangement before undergoing any compositional change [44, 45].

3) The negative $\Delta S$ values for the decomposition steps indicate that all studied complexes are more ordered in their activated states [44].

4) The positive $\Delta \mathrm{H}$ values mean that the decomposition processes are endothermic [46].

Table 4: Kinetic parameters evaluated by Coats-Redfern equation

\begin{tabular}{|l|c|c|c|c|c|c|c|}
\hline \multicolumn{1}{|c|}{ Complex } & Stage & $\mathrm{T}(\mathrm{K})$ & $\mathrm{A}\left(\mathrm{S}^{-1}\right)$ & $\begin{array}{c}\mathrm{E}_{\mathrm{a}} \\
(\mathrm{kJ} / \mathrm{mol})\end{array}$ & $\Delta \mathrm{H}(\mathrm{kJ} / \mathrm{mol})$ & $\begin{array}{c}\Delta \mathrm{S} \\
(\mathrm{kJ} / \mathrm{mol} \mathrm{K})\end{array}$ & $\begin{array}{c}\Delta \mathrm{G} \\
(\mathrm{kJ} / \mathrm{mol})\end{array}$ \\
\hline$\left[\mathrm{Fe}(\right.$ DPTMEBPP $\left.)\left(\mathrm{NO}_{3}\right)_{3}\left(\mathrm{H}_{2} \mathrm{O}\right)_{2}\right] \cdot 6.75 \mathrm{H}_{2} \mathrm{O}$ & $1 \mathrm{st}$ & 436 & $21.03 \times 10^{5}$ & 169.88 & 112.22 & -0.045 & 163 \\
\cline { 2 - 8 } & $2 \mathrm{nd}$ & 567 & $48.77 \times 10^{7}$ & 188.39 & 125.69 & -0.065 & 196 \\
\cline { 2 - 8 } & $3 \mathrm{rd}$ & 798 & $73.39 \times 10^{10}$ & 197.33 & 154.48 & -0.075 & 232 \\
\hline$\left[\mathrm{Cu}\left(\right.\right.$ DPTMEBPP)$\left.(\mathrm{OAc})_{2}\right] \cdot \mathrm{H}_{2} \mathrm{O}$ & $1 \mathrm{st}$ & 432 & $48.87 \times 10^{6}$ & 68.56 & 68.75 & -0.085 & 159 \\
\cline { 2 - 8 } & $2 \mathrm{nd}$ & 587 & $22.64 \times 10^{7}$ & 134.88 & 98.38 & -0.110 & 188 \\
\cline { 2 - 8 } & $3 \mathrm{rd}$ & 800 & $58.75 \times 10^{9}$ & 176.53 & 123.89 & -0.166 & 225 \\
\hline$\left[\mathrm{Pb}\left(\right.\right.$ DPTMEBPP)$\left.-(\mathrm{OAc})_{2}\right] \cdot 3 \mathrm{H}_{2} \mathrm{O}$ & $1 \mathrm{st}$ & 457 & $95.49 \times 10^{7}$ & 134.73 & 97.12 & -0.036 & 158 \\
\cline { 2 - 8 } & $2 \mathrm{nd}$ & 507 & $24.89 \times 10^{7}$ & 158.82 & 134.88 & -0.066 & 182 \\
\cline { 2 - 8 } & $3 \mathrm{rd}$ & 794 & $97.32 \times 10^{9}$ & 188.63 & 154.43 & -0.077 & 249 \\
\hline$\left[\mathrm{La}(\right.$ DPTMEBPP $)\left(\mathrm{Cl}_{3}\left(\mathrm{H}_{2} \mathrm{O}\right)_{2}\right] \cdot 6 \mathrm{H}_{2} \mathrm{O}$ & $1 \mathrm{st}$ & 448 & $12.77 \times 10^{9}$ & 58.58 & 64.74 & -0.029 & 166 \\
\cline { 2 - 8 } & $2 \mathrm{nd}$ & 569 & $8.65 \times 10^{11}$ & 85.78 & 64.38 & -0.077 & 183 \\
\cline { 2 - 8 } & $3 \mathrm{rd}$ & 800 & $16.94 \times 10^{6}$ & 133.84 & 94.64 & -0.085 & 198 \\
\hline
\end{tabular}

Table 5: Kinetic parameters evaluated by Horowitz-Metzger equation

\begin{tabular}{|c|c|c|c|c|c|c|c|}
\hline Complex & Stage & $\mathrm{T}(\mathrm{K})$ & $\mathrm{A}\left(\mathrm{S}^{-1}\right)$ & $\begin{array}{c}\mathrm{E}_{\mathrm{a}} \\
(\mathrm{kJ} / \mathrm{mol})\end{array}$ & $\begin{array}{c}\Delta \mathrm{H} \\
(\mathrm{kJ} / \mathrm{mol})\end{array}$ & $\begin{array}{c}\Delta \mathrm{S} \\
(\mathrm{kJ} / \mathrm{mol} \mathrm{K})\end{array}$ & $\begin{array}{c}\Delta \mathrm{G} \\
(\mathrm{kJ} / \mathrm{mol})\end{array}$ \\
\hline \multirow{3}{*}{$\begin{array}{c}{\left[\mathrm{Fe}(\mathrm{DPTMEBPP})\left(\mathrm{NO}_{3}\right)_{3}(\mathrm{H}\right.} \\
\left.\left.{ }_{2} \mathrm{O}\right)_{2}\right] \cdot 6.75 \mathrm{H}_{2} \mathrm{O}\end{array}$} & $1 \mathrm{st}$ & 436 & $21.78 \times 10^{5}$ & 169.74 & 112.43 & -0.045 & 162 \\
\hline & 2nd & 567 & $48.94 \times 10^{7}$ & 188.12 & 125.71 & -0.065 & 194 \\
\hline & $3 r d$ & 798 & $73.32 \times 10^{10}$ & 197.36 & 154.49 & -0.075 & 231 \\
\hline \multirow{3}{*}{$\begin{array}{c}{\left[\mathrm{Cu}(\mathrm{DPTMEBPP})(\mathrm{OAc})_{2}\right] .} \\
\mathrm{H}_{2} \mathrm{O}\end{array}$} & $1 \mathrm{st}$ & 432 & $48.98 \times 10^{6}$ & 68.42 & 68.74 & -0.085 & 160 \\
\hline & 2 nd & 587 & $22.70 \times 10^{7}$ & 134.75 & 98.59 & -0.110 & 189 \\
\hline & $3 \mathrm{rd}$ & 800 & $58.87 \times 10^{9}$ & 176.53 & 124.71 & -0.166 & 224 \\
\hline \multirow{3}{*}{$\begin{array}{l}{[\mathrm{Pb}(\mathrm{DPTMEBPP})-} \\
\left.(\mathrm{OAc})_{2}\right] \cdot 3 \mathrm{H}_{2} \mathrm{O}\end{array}$} & $1 \mathrm{st}$ & 457 & $95.58 \times 10^{7}$ & 134.76 & 96.96 & -0.036 & 158 \\
\hline & $2 \mathrm{nd}$ & 507 & $24.76 \times 10^{7}$ & 158.97 & 134.69 & -0.066 & 181 \\
\hline & $3 \mathrm{rd}$ & 794 & $97.22 \times 10^{9}$ & 188.96 & 154.46 & -0.077 & 250 \\
\hline \multirow{3}{*}{$\begin{array}{c}{\left[\mathrm{La}(\mathrm{DPTMEBPP})(\mathrm{Cl})_{3}\left(\mathrm{H}_{2}\right.\right.} \\
\left.\mathrm{O})_{2}\right] \cdot 6 \mathrm{H}_{2} \mathrm{O}\end{array}$} & $1 \mathrm{st}$ & 448 & $12.61 \times 10^{9}$ & 58.97 & 64.38 & -0.029 & 167 \\
\hline & $2 \mathrm{nd}$ & 569 & $8.34 \times 10^{11}$ & 85.95 & 64.55 & -0.077 & 182 \\
\hline & $3 \mathrm{rd}$ & 800 & $16.74 \times 10^{6}$ & 133.94 & 94.05 & -0.085 & 199 \\
\hline
\end{tabular}




\section{International Journal of Science and Research (IJSR) \\ ISSN (Online): 2319-7064}

Index Copernicus Value (2013): 6.14 | Impact Factor (2014): 5.611

\begin{tabular}{|c|c|c|c|c|c|c|c|}
\hline Complex & Stage & $\mathrm{T}(\mathrm{K})$ & $\mathrm{A}\left(\mathrm{S}^{-1}\right)$ & $\begin{array}{c}\mathrm{E}_{\mathrm{a}} \\
(\mathrm{kJ} / \mathrm{mol})\end{array}$ & $\Delta \mathrm{H}(\mathrm{kJ} / \mathrm{mol})$ & $\begin{array}{c}\Delta \mathrm{S} \\
(\mathrm{kJ} / \mathrm{mol} \mathrm{K})\end{array}$ & $\begin{array}{c}\Delta \mathrm{G} \\
(\mathrm{kJ} / \mathrm{mol})\end{array}$ \\
\hline \multirow{3}{*}{$\begin{array}{c}{\left[\mathrm{Fe}(\mathrm{DPTMEBPP})\left(\mathrm{NO}_{3}\right)\right.} \\
\left.{ }_{3}\left(\mathrm{H}_{2} \mathrm{O}\right)_{2}\right] \cdot 6 \cdot 75 \mathrm{H}_{2} \mathrm{O}\end{array}$} & $1 \mathrm{st}$ & 436 & $21.69 \times 10^{5}$ & 169.86 & 112.34 & -0.046 & 164 \\
\hline & 2nd & 567 & $48.85 \times 10^{7}$ & 188.34 & 125.68 & -0.064 & 196 \\
\hline & $3 \mathrm{rd}$ & 798 & $73.21 \times 10^{10}$ & 197.38 & 154.43 & -0.076 & 233 \\
\hline \multirow{3}{*}{$\begin{array}{c}{\left[\mathrm{Cu}(\mathrm{DPTMEBPP})(\mathrm{OAc})_{2}\right] .} \\
\mathrm{H}_{2} \mathrm{O}\end{array}$} & $1 \mathrm{st}$ & 432 & $48.86 \times 10^{6}$ & 68.58 & 68.96 & -0.086 & 159 \\
\hline & 2 nd & 587 & $22.53 \times 10^{7}$ & 134.83 & 98.41 & -0.111 & 187 \\
\hline & $3 \mathrm{rd}$ & 800 & $58.34 \times 10^{9}$ & 176.59 & 123.96 & -0.167 & 224 \\
\hline \multirow{3}{*}{$\begin{array}{l}{[\mathrm{Pb}(\mathrm{DPTMEBPP})-} \\
\left.(\mathrm{OAc})_{2}\right] \cdot 3 \mathrm{H}_{2} \mathrm{O}\end{array}$} & $1 \mathrm{st}$ & 457 & $95.73 \times 10^{7}$ & 134.77 & 97.03 & -0.035 & 159 \\
\hline & 2nd & 507 & $24.88 \times 10^{7}$ & 158.89 & 134.97 & -0.065 & 183 \\
\hline & $3 \mathrm{rd}$ & 794 & $97.89 \times 10^{9}$ & 188.75 & 154.47 & -0.076 & 249 \\
\hline \multirow{3}{*}{$\begin{array}{c}{\left[\mathrm{La}(\mathrm{DPTMEBPP})(\mathrm{Cl})_{3}\left(\mathrm{H}_{2} \mathrm{O}\right.\right.} \\
\left.)_{2}\right] .6 \mathrm{H}_{2} \mathrm{O}\end{array}$} & $1 \mathrm{st}$ & 448 & $12.73 \times 10^{9}$ & 58.66 & 64.99 & -0.024 & 166 \\
\hline & 2nd & 569 & $8.53 \times 10^{11}$ & 85.73 & 64.46 & -0.074 & 184 \\
\hline & $3 \mathrm{rd}$ & 800 & $16.88 \times 10^{6}$ & 133.90 & 94.41 & -0.088 & 197 \\
\hline
\end{tabular}

\subsection{Conclusions}

The synthesized diphenyl (2-amino-5-(3,4,5trimethoxybenzyl)pyrimidin-4-yl-phosphoramidate (DPTMEBPP) act as bidentate ligand. The metals are coordinated to azomethine nitrogen and phenolic oxygen atoms. The analytical, IR, NMR, ESR, XRD, mass, electronic, magnetic, and thermal studies confirm the bonding of phosphoramidate ligand (DPTMEBPP) to metal ions. All these observations put together lead us to propose the following structure (Fig. 5) in which, the complexes having the stoichiometry of the type [M(III)L $\left.\left(\mathrm{H}_{2} \mathrm{O}\right)_{\mathrm{n}} \mathrm{Yx}\right] \cdot \mathrm{zH}_{2} \mathrm{O}\left(\mathrm{M}=\mathrm{Fe}(\mathrm{III}) ; \mathrm{n}=2, \mathrm{Y}=\mathrm{NO}_{3}, \mathrm{x}=3, \mathrm{Z}=\right.$ 6.75 $\mathrm{H}_{2} \mathrm{O}$ and $\left.\mathrm{M}=\mathrm{La}(\mathrm{III}) ; \mathrm{n}=2, \mathrm{Y}=\mathrm{Cl}, \mathrm{x}=3, \mathrm{Z}=6 \mathrm{H}_{2} \mathrm{O}\right)$ and $\left[\mathrm{M}(\mathrm{II}) \mathrm{L}(\mathrm{OAc})_{2}\left(\mathrm{H}_{2} \mathrm{O}\right)_{\mathrm{n}}\right] . \mathrm{XH}_{2} \mathrm{O}(\mathrm{M}=\mathrm{Mn}(\mathrm{II}) ; \mathrm{n}=2, \mathrm{X}=2, \mathrm{M}=$ $\mathrm{Co}(\mathrm{II}) ; \mathrm{n}=2, \mathrm{X}=2, \mathrm{M}=\mathrm{Ni}(\mathrm{II}) ; \mathrm{n}=2, \mathrm{X}=2, \mathrm{M}=\mathrm{Cu}(\mathrm{II}) ; \mathrm{n}=0$, $\mathrm{X}=1, \mathrm{M}=\mathrm{Zn}(\mathrm{II}) ; \mathrm{n}=0, \mathrm{X}=2$ and $\mathrm{M}=\mathrm{Pb}(\mathrm{II}) ; \mathrm{n}=0, \mathrm{X}=3)[\mathrm{L}=$ DPTMEBPP].<smiles>COc1cc(Cc2cnc(NC(C)(O)C[N+](=O)[O-])nc2NC(=O)[N+](=O)[O-])cc(OC)c1OC</smiles>

$6.75 \mathrm{H}_{2} \mathrm{O}$<smiles>COc1cc(Cc2cnc(NC(C)(O)C(C)(C)O)nc2NC(C)(C)O)cc(OC)c1OP(=O)(Oc1ccccc1)Oc1ccccc1</smiles><smiles>COc1cc(Cc2cnc(NC(C)(O)C(C)(O)O)nc2NC(=O)OP(=O)(Oc2ccccc2)Oc2ccccc2)cc(OC)c1OC</smiles>
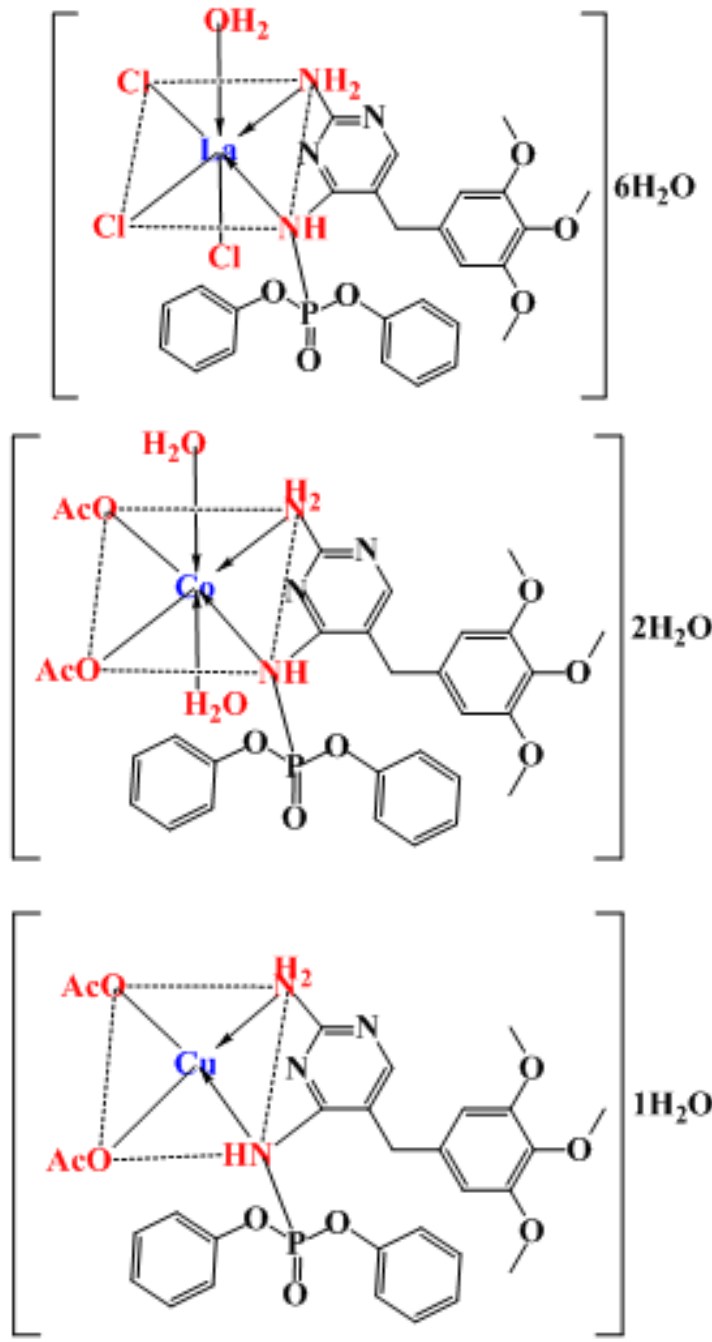

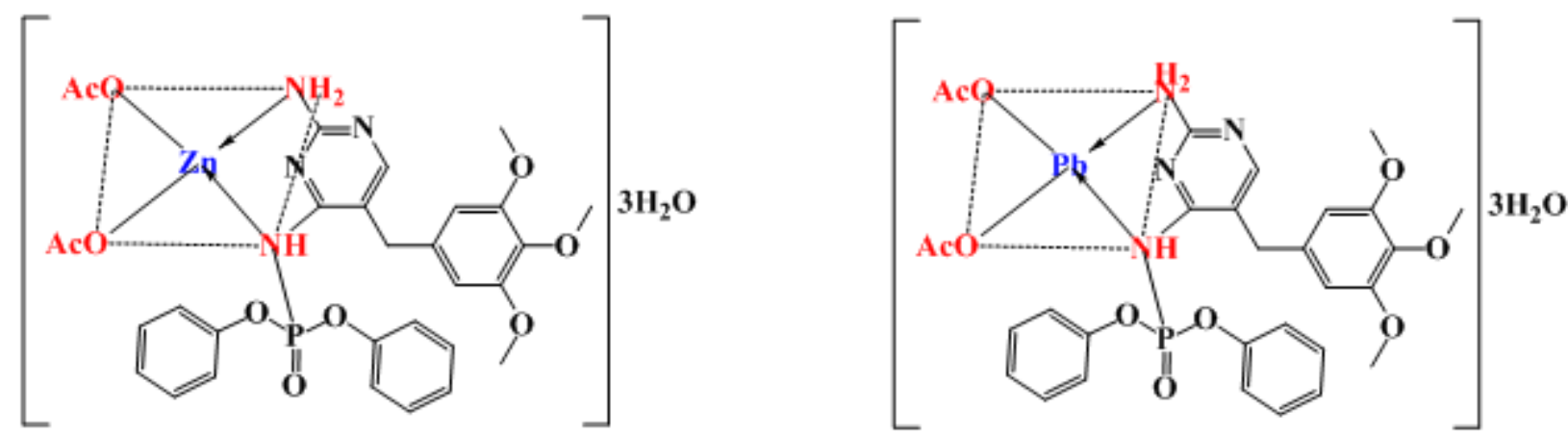

Figure 4: Proposed structures of the metal complexes

\section{References}

[1] N. Demirezen, D. Tarınç, D. Polat, M. Çeşme, A. Gölcü, M. Tümer, Spectrochimica Acta A 94 (2012) 243- 255.

[2] P.J. Sadler, Adv. Inorg. Chem. 36 (1991) 1-48.

[3] N. Saha, S. Kar, J. Inorg. Nucl. Chem. 39 (1977) 195-200.

[4] D. Kovala, N. Hadjiliadis, J. Tsangaris, J. Less Common Met. 115 (1986) 1-5.

[5] J. Tsangaris, D. Sotiropoulos, A. Galinos, Inorg. Nucl. Chem. Lett. 14 (1978) 445-449.

[6] F. Demartin, M. Manassero, L. Naldini, M. Zoroddu, Inorg. Chim. Acta 213 (1983) L213-L214.

[7] L. Naldini, M. Cabras, M. Zoroddu, F. Demartin, M. Manassero, M. Sansoni, Inorg. Chim. Acta 88 (1984) 4550.

[8] M. Zoroddu, L. Naldini, F. Demartin, N. Masciocchi, Inorg. Chim. Acta 128 (1987) 179-183.

[9] F. Demartin, N. Masciocchi, L. Naldini, A. Panzanelli, M. Zoroddu, Inorg. Chim. Acta 171 (1990) 229-233.

[10] P.T. Muthiah, J.J. Robert, J. Chem. Crystallogr. 29 (1999) 223-226.

[11] B. Seekhon, H. Randhawa, H. Sahai, Synth. React. Inorg. Met.-Org. Chem. 29 (1999) 309-321.

[12] J.E. Weder, C.T. Dillon, T.W. Hambley, B.J. Kennedy, P.A. Lay, J.R. Biffin, H.L. Regtop, N.M. Davis, Coord. Chem. Rev. 232 (2002) 95-126.

[13] P.A. Ajibade, G.A. Kolawole, Transit. Met. Chem. 33 (2008) 493-497.

[14] M.J. Clarke, Coord. Chem. Rev. 236 (2003) 207-231.

[15] P.A. Ajibade, G.A. Kolawole, Synth. React. Inorg. Met.Org. Chem. 40 (2010) 273-278.

[16] N. Demirezen, D. Tarınç, D. Polat, M. Çeşme, A. Gölcü, M. Tümer, Spectrochimica Acta A 94 (2012) 243- 255.

[17] L. Rajith, K.G. Kumar, Drug Test. Anal. 2 (2010) 436441.

[18] A.M.A. Alaghaz, R.A. Ammar, European Journal of Medicinal Chemistry 45 (2010) 1314-1322.

[19] A.M.A. Alaghaz, Journal of Molecular Structure 1068 (2014) 27-4245.

[20] A.M.A. Alaghaz, A.G. Al-Sehemi, T.M. EL-Gogary, Spectrochimica Acta Part A: Molecular and Biomolecular Spectroscopy 95 (2012) 414-422.

[21] A.M.A. Alaghaz, R.A.A. Ammar, G.Koehler, K.P. Wolschann, T.M. El-Gogary, Spectrochimica Acta Part A: Molecular and Biomolecular Spectroscopy 128 (2014) 724-729.

[22] K. Nakamoto, Infrared Spectra of Inorganic and Coordination Compounds, Wiley Interscience, New York, 1970.

[23] A.B.P. Lever, Crystal Field Spectra. Inorganic Electronic Spectroscopy, first ed., Elsevier Amsterdam, 1968.;A.B.P.
Lever, Electronic Spectra of Inorganic and Coordination Compounds, John Wiley, New York, 1968.

[24] A. M.A. Alaghaz, Molec. Struct. 1072 (2014) 103-113.

[25] A.B.P. Lever, Inorg. Electronic Spectroscopy, second ed. Elsevier, Amsterdam, 1984.

[26] A. M.A. Alaghaz, B. A. El-Sayed, A. A. El-Henawy, R. A.A. Ammar, Molecu. Struct. 1035 (2013) 83-93.

[27] R.S. Drago, Physical Methods in Chemistry, W.B. Saunders Company, London, 1977.

[28] D.M. Hong, H.H.Wei, L.L. Gan, G.H. Lee,Y.Wang, Polyhedron 15 (1996) 2335.

[29] S. Chandra, S.D. Sharma, Trans. Met. Chem. 27 (2002) 733.

[30] A. Abragam, B. Bleaney, Electron Paramagnetic Resonance of Transition Ions, Oxford University Press, Oxford, 1970.

[31] F.E. Mabbs, D. Collison, Electron Paramagnetic Resonance of Transition Metal Compounds, Elsevier, Amsterdam, 1992.

[32] S. Chandra, R. Kumar, Spectrochimica Acta Part A 66 (2007) 74-80.

[33] J. Owen, Proc. Roy. Soc. London, A 227 (1955) 183.

[34] S.V. Rosoka, Y.D. Lampeka, I.M. Maloshtan, Dalton Trans. (1993) 631.

[35] S. Chandra, Ruchi, Spectrochimica Acta Part A 103 (2013) 338-348.

[36] B. Singh, B.P. Yadav, R.C. Aggarwal, Ind. J. Chem A. 23 (1984) 441-444.

[37] S. Chandra, R. Gupta, N. Gupta, S.S. Bava, Synth. React. Inorg. Metal-Org. Nano-Met. Chem. 35 (2005) 883-888.

[38] R. Shirley, The CRYSFIRE System for Automatic Powder Indexing: User's Manual, Lattice Press, 2002.

[39] H.H. Horowitz, G. Metzger, Anal. Chem. 35 (1963) 14641468.

[40] A.W. Coats, J.P. Redfern, Nature 20 (1964) 68-69.

[41] G.O. Piloyan, T.D. Pyabonikar, C.S. Novikova, Nature, 212 (1966) 1229-1304.

[42] T. Taakeyama, F.X. Quinn, Thermal Analysis Fundamentals and Applications to Polymer Science, John Wiley and Sons, Chichester, 1994.

[43] P.B. Maravalli, T.R. Goudar, Thermochim. Acta 325 (1999) 35-41.

[44] K.K.M. Yusuff, R. Sreekala, Thermochim. Acta 159 (1990) 357-368.

[45] S.S. Kandil, G.B. El-Hefnawy, E.A. Baker, Thermochim. Acta 414 (2004) 105-113.

[46] L.T. Valaev, G.G. Gospodinov, Thermochim. Acta 370 (2001) 15-19. 